\title{
Low Oxygen Treatment prior to cold storage to maintain the quality of apples at industrial scale
}

\author{
A. Díaz ${ }^{1}$, M. Pérez², D. Redondo ${ }^{1}$ and J. Val ${ }^{1, a}$.
}

1Plant Nutrition Department. Estación Experimental de Aula Dei (EEAD-CSIC), Avda. Montañana 1005. 50059, Zaragoza, Spain.

2Parque Científico Tecnológico de Aula Dei (PCTAD), Avenida Montañana 930. 50059 Zaragoza, Spain.

\section{Abstract}

A great proportion of losses in apple production can be attributed to fruit physiological diroders, usually revealed during cold storage. These losses are commonly associated with metabolic processes in which calcium is involved. After years of study and experimentation in an attempt for reducing the incidence of Ca-related disorders by exogenous calcium treatments, a study published by Edna Pesis in 2007 opened another research route in this regard. This study, in Granny Smith, revealed that applying a treatment of low oxygen at room temperature, a considerable reduction of scald was achieved and pointed to a possible effect on alleviating bitter pit. It was hypothesized that low oxygen treatments may delay the metabolic activity of fruits and also delay ripening, softening and withering. Since 2008, we have continued to deepen into the development of alternative methods of low environmental impact which avoid the use of chemicals. Strategies have been developed for the application of LOT (Low Oxygen Treatment) treatments at room temperature in various apple varieties, obtaining promising results at the lab and at the semi-industrial scale. In this paper, LOT technology has been validated, this time, on an industrial scale. An Ilerfred system, with monitoring and control of $\mathrm{CO}_{2}$ and $\mathrm{O}_{2}$, was used. The LOT followed by conventional cold storage has proved too be very effective for the control of rots in all varieties, and was able to effectively control 'lenticel blotch pit' in Reinette. The results of the 2016 campaign compared to those of the two previous seasons allow us to conclude that improvement in shelf life of apples is achieved by combining different LOT conditions with the Dynamic Controlled Atmosphere (DCA) storage technology.

Keywords: bitter pit, fruit quality, fruit physiological disorders, lenticel blotch pit, shelf life.

\section{INTRODUCTION}

The storage of horticultural products aims to slow the metabolism of commodities and to expand their shelf-life. After harvest, fruit pulp firmness decreases gradually, some loss of aroma is registered, acid content and sucrose are reduced, weight loss due to transpiration is increased and, under certain conditions, some physiological disorders and rot alterations are developed (Benítez, 2001). The main factor that limits shelf-life of these commodities is the metabolic activity of fruits that continues even after harvest. The processes of respiration, transpiration and

a E-mail: jesus.val@csic.es 
production of ethylene have to be thoroughly controlled to extend the optimum maturation degree of these foods until their consumption. If these reactions progress too rapidly, fruits may ripen excessively, soften and wilt their tissues, and decrease their quality considerably, favoring the appearance of physiological disorders.

Current storage technologies for plant foods allow long-term storage of pome fruits such as apples. However, the appearance of physiological disorders during cold storage causes significant losses in terms of fruit quality and economic value. Some authors have successfully applied low impact techniques to reduce these losses. Pesis et al. (2007) reported that applying a low oxygen pre-treatment at $20{ }^{\circ} \mathrm{C}$ in 'Granny Smith' apples achieved a considerable reduction of apple scald and pointed to a possible effect on bitter pit in this variety. It was hypothesized that low oxygen treatments may delay metabolic activity of fruits and also delay ripening, softening and withering. The Nutrition of Fruit Crops research group from Aula Dei Experimental Station have continued to deepen into the development of alternative methods of low environmental impact which avoid the use of chemicals. We have demonstrated that, applying this technology, significant reduction in the percentage of affected fruits by bitter pit, better quality and longer shelf-life were achieved (Val et al., 2010). Moreover, after 4 months of storage, treated fruits showed higher firmness and soluble solid content and a brighter yellow color than control ones. From these results can be deduced that treatment with low oxygen at room temperature confers to the treated fruits exceptional organoleptic and quality characteristics.

For all of this, the aim of this work is to take a step forward regarding the application of LOT in order to validate this technology in terms of quality and physiological disorders on an industrial scale in 'Golden Delicious' apples.

\section{MATERIALS AND METHODS}

\section{Fruit samples}

Apples (Malus domestiva 'Golden Delicious') were manually harvest at random in a commercial orchard located in the Mid-Ebro Valley (La Almunia de Doña Godina, Zaragoza, Spain) at the time of optimum commercial harvest (September 18, 2014; October 24, 2015: October 17, 2016). Samples were transferred immediately to the facilities of Agricola Gil Company (Urrea de Jalón, Zaragoza, Spain) where the LOT was carried out.

\section{Experimental design}

The fruits where divided in two groups: control and LOT batches. Control samples were stored at $0-1{ }^{\circ} \mathrm{C}$ and $85 \%$ RH for 100 days. In parallel, LOT samples were stored under low $\mathrm{O}_{2}(0-1 \%)$ at room temperature $\left(20^{\circ} \mathrm{C}\right)$ in Palliflex bags for 10 days using an Ilerfred system (Lérida, Spain) for monitoring and control of $\mathrm{CO}_{2}$ and $\mathrm{O}_{2}$. Thereafter, fruits were cold-stored $\left(0-2{ }^{\circ} \mathrm{C}\right)$ without bag for 98 days and changes were monitored. Quality parameters were determined at harvest and after 100 days of storage.

\section{Quality parameters}

To evaluate quality, destructive and non-destructive methods were used. Twenty fruits per experimental unit were analyzed. Color coordinates were determined using 
the CIELab color space with the aid of a spectrophotometer (Konica Minolta mod. CMS 700; Tokyo, Japan). Firmness was measured by destructive Magness-Taylor using a digital penetrometer (Agrosta; Forges Les Eaux, France) with a tip diameter of $11 \mathrm{~mm}$ and expressing the results as kg. Soluble solid content (SSC) as Brix degrees was determined by crushing the flesh and transferring the intact juice of the 10 samples to a digital refractometer (Atago mod. PR-101; Tokyo, Japan). Titratable acidity (TA) by an automatic titrator (Mettler Toledo mod. G20 Compact Titrator; New York, NY, USA). Ten grams of juice from 10 fruits were brought to $60 \mathrm{~mL}$ of distilled $\mathrm{H}_{2} \mathrm{O}$ and titrated with $0.1 \mathrm{~mol} \mathrm{~L}^{-1} \mathrm{NaOH}$ solution up to $\mathrm{pH}$ 8.1, expressing the results as g malic acid per $\mathrm{kg}$.

\section{Respiration rates}

Respiratory activity and ethylene concentration, were determined in three intact apples per sample which were introduced in a glass jar, sealed and kept at $20{ }^{\circ} \mathrm{C}$ for 3 hours. The headspace gas composition was analyzed for $\mathrm{O}_{2}$ and $\mathrm{CO}_{2}$ with an automatic gas analyzer (PBI Dansensor; Barcelona, Spain) and for ethylene concentration by gas chromatography (Hewlett Packard 4890) with FID detector and a stainless steel column (Hewlett Packard 19001 A-QSO). Injector, detector and oven temperatures were set at 50, 200 and $50{ }^{\circ} \mathrm{C}$, respectively, and the carrier gas was nitrogen. Measurements were made in triplicate for each batch and the results expressed as $\mathrm{mL}$ $\mathrm{kg}^{-1} \mathrm{~h}^{-1}$ for $\mathrm{O}_{2}$ and as $\mu \mathrm{Lg}^{-1} \mathrm{~h}^{-1}$ for ethylene. All determinations were performed at atmospheric pressure and room temperature.

\section{Physiological alterations}

After 100 days of cold storage, 100 fruits per batch were evaluated for the incidence of bitter pit, lenticel blotch pit, scald and rots, expressing the results as percentage.

\section{Sensory analysis}

A descriptive test was done with a trained panel. This panel was formed by 10 persons ( 4 men and 6 women) that had already participated in sensory sessions in the past. The panel was trained for quantitative descriptive analysis and the components received three 60-min training sessions prior to formal sessions. The selected parameters for the visual phase were visual aspect and firmness to the touch and for the taste phase were texture, crunchy, juiciness, mealiness and flavor intensity. All these parameters were ranked from 0 to 10 .

\section{Statistical analysis}

All samples were analyzed in triplicate per year and the results presented as mean values \pm standard deviation. Statistical analyses were performed using a one-way ANOVA test and the significance of the difference between means was determined by Duncan's multiple range test $(p<0.05)$. Statistical analysis was performed using the Statistical Package for the Social Science (SPSS) software version 22.0.

\section{RESULTS AND DISCUSSION}


Quality parameters of 'Golden Delicious' apples at harvest and after 100 days of cold storage for the three seasons are shown in Table 1. Destructive firmness and nondestructive Aweta values decrease during cold storage in all three seasons and, in general terms, the values were higher for LOT samples than for those of control recording statistical significant differences $(p \leq 0.05)$ for 2014 and 2015 seasons. This finding had already been reported by our research group (Val et al., 2010; Pérez et al., 2012; Pérez et al., 2016). Moreover, SSC increased in season 2016, an effect also observed previously by our research group (Val et al., 2010). No changes in $\mathrm{L}^{*}$, $\mathrm{a}^{*}$ and $b^{*}$ coordinates were registered between treatments. However, the acidity was higher for LOT, with significant differences $(p \leq 0.05)$ in 2014 season which might indicate a high flavor for the LOT apples compared with the control ones.

Table 1. Evolution of quality parameters in 'Golden Delicious' apples at harvest and after 100 days of cold storage*.

\begin{tabular}{lccccccc}
\hline & $\begin{array}{c}\text { Firmness } \\
(\mathrm{kg})\end{array}$ & Aweta & $\begin{array}{c}\text { SSC } \\
\left({ }^{\circ} \text { Brix }\right)\end{array}$ & $\begin{array}{c}\text { TA } \\
(\text { g malic acid kg-1) }\end{array}$ & $\begin{array}{c}\mathrm{L}^{*} \\
(\mathrm{D} 65)\end{array}$ & $\begin{array}{c}\mathrm{a}^{*} \\
(\mathrm{D} 65)\end{array}$ & $\begin{array}{c}\mathrm{b}^{*} \\
(\mathrm{D} 65)\end{array}$ \\
\hline $\mathbf{2 0 1 4}$ & & & & & & & \\
\hline Harvest & $7.00 \mathrm{a}$ & $28.62 \mathrm{a}$ & $15.77 \mathrm{~b}$ & $6.02 \mathrm{a}$ & $75.79 \mathrm{a}$ & $-3.29 \mathrm{a}$ & 43.81 \\
Control & $6.22 \mathrm{~b}$ & $20.33 \mathrm{c}$ & $16.50 \mathrm{a}$ & $3.47 \mathrm{c}$ & $72.34 \mathrm{~b}$ & $1.24 \mathrm{~b}$ & 44.84 \\
LOT & $6.50 \mathrm{~b}$ & $22.81 \mathrm{~b}$ & $16.53 \mathrm{a}$ & $4.01 \mathrm{~b}$ & $75.35 \mathrm{a}$ & $1.56 \mathrm{~b}$ & 46.94 \\
\hline $\mathbf{2 0 1 5}$ & & & & & & & \\
\hline Harvest & $6.84 \mathrm{a}$ & $23.14 \mathrm{a}$ & $14.83 \mathrm{a}$ & $3.35 \mathrm{a}$ & 75.70 & $0.70 \mathrm{a}$ & $47.66 \mathrm{a}$ \\
Control & $3.89 \mathrm{c}$ & $10.06 \mathrm{~b}$ & $13.60 \mathrm{~b}$ & $1.52 \mathrm{~b}$ & 74.93 & $5.15 \mathrm{~b}$ & $50.08 \mathrm{~b}$ \\
LOT & $4.34 \mathrm{~b}$ & $6.74 \mathrm{c}$ & $13.58 \mathrm{~b}$ & $1.71 \mathrm{~b}$ & 74.83 & $4.69 \mathrm{~b}$ & $50.52 \mathrm{~b}$ \\
\hline $\mathbf{2 0 1 6}$ & & & & & & & \\
\hline Harvest & $6.01 \mathrm{a}$ & $28.68 \mathrm{a}$ & $13.13 \mathrm{ab}$ & $4.57 \mathrm{a}$ & 74.36 & $-4.51 \mathrm{a}$ & 40.56 \\
Control & $4.04 \mathrm{~b}$ & $16.05 \mathrm{~b}$ & $12.40 \mathrm{a}$ & $2.67 \mathrm{~b}$ & 72.16 & $1.65 \mathrm{~b}$ & 41.72 \\
LOT & $4.43 \mathrm{~b}$ & $19.02 \mathrm{~b}$ & $13.58 \mathrm{~b}$ & $3.59 \mathrm{ab}$ & 73.48 & $1.89 \mathrm{~b}$ & 41.23 \\
\hline
\end{tabular}

"different letters in the same column indicate significant differences $(p \leq 0.05)$ between treatments for the same year.

The rapport of physiological alterations in these fruits after 100 days of storage is shown in Table 2. Low incidence of bitter pit was observed in all three seasons. In 2016 a slight incidence was recorder but with no significant differences between treatments. Regarding others calcium related physiological disorders as lenticel blotch pit, LOT reduce significantly the incidence in 2014, from 34.8 to 5.1\%. Moreover, 2015 season was the only with registered mold rots, being LOT effective to reduce their appearance. However, LOT seams to induce a slight superficial scald during storage, with significant differences $(p \leq 0.05)$ in 2014 and 2016, although only in 2014 the percentage was higher (36.4\%).

Table 2. Percentage of different physiological disorders in 'Golden Delicious' apples after 100 days of cold storage.

\begin{tabular}{lcccc} 
& Bitter pit & $\begin{array}{c}\text { Lenticel } \\
\text { blotch pit }\end{array}$ & Scald & Mold rots \\
\hline $\mathbf{2 0 1 4}$ & & & & \\
\hline Control & 0 & $34.8 \mathrm{a}$ & $25.3 \mathrm{~b}$ & 0 \\
LOT & 0 & $5.1 \mathrm{~b}$ & $36.4 \mathrm{a}$ & 0 \\
\hline $\mathbf{2 0 1 5}$ & & & & \\
\hline Control & 0 & 0 & 2.6 & $42.1 \mathrm{a}$ \\
LOT & 0 & 0 & 5.1 & $16.2 \mathrm{~b}$ \\
\hline
\end{tabular}




\begin{tabular}{lllll}
\hline $\mathbf{2 0 1 6}$ & & & & \\
\hline Control & 5.0 & 5.9 & $0.0 \mathrm{~b}$ & 0 \\
LOT & 7.4 & 6.4 & $6.0 \mathrm{a}$ & 0 \\
\hline
\end{tabular}

The respiration activity was only affected by LOT in 2014 season (Table 3). A decrease in the consumption of oxygen and in the production of ethylene was observed, indicating that this treatment might affect the respiration rates of these fruits and therefore, increase their shelf-life. The fact that this changes only were observed for the 2014 season might be due to the different agro-climatic conditions between the years of the study.

\begin{tabular}{|c|c|c|}
\hline \multicolumn{3}{|c|}{$\begin{array}{l}\text { Table 3. respiration and ethylene production in 'Golden Delicious' appl } \\
\text { at harvest and after } 100 \text { days of cold storage. }\end{array}$} \\
\hline & $\mathrm{O}_{2}\left(\mu \mathrm{L} \mathrm{kg}^{-1} \mathrm{~h}^{-1}\right)$ & Ethylene $\left(\mu \mathrm{Lg}^{-1} \mathrm{~h}^{-1}\right)$ \\
\hline \multicolumn{3}{|l|}{2014} \\
\hline Harvest & $14.8 \mathrm{a}$ & $21.6 \mathrm{~b}$ \\
\hline Control & $15.7 \mathrm{a}$ & $40.0 \mathrm{a}$ \\
\hline LOT & $11.9 \mathrm{~b}$ & $0.8 \mathrm{c}$ \\
\hline \multicolumn{3}{|l|}{2015} \\
\hline Harvest & $12.08 \mathrm{~b}$ & $25.7 \quad b$ \\
\hline Control & $22.2 \mathrm{a}$ & $118.2 \mathrm{a}$ \\
\hline LOT & $23.9 \mathrm{a}$ & $106.5 \mathrm{a}$ \\
\hline \multicolumn{3}{|l|}{2016} \\
\hline Harvest & $9.43 \mathrm{~b}$ & $0.42 \quad b$ \\
\hline Control & $15.13 \mathrm{a}$ & $14.90 \mathrm{a}$ \\
\hline LOT & $17.41 \mathrm{a}$ & $16.77 \mathrm{a}$ \\
\hline
\end{tabular}

The sensorial analysis shows a positive effect of LOT (Table 4). Although no differences between treatments were observed in the visual phase, LOT was positive in all the taste phase parameters with no off flavors or fermented aromas, showing that can be an interesting technology to improve shelf-life.

Table 4. Sensorial analysis of 'Golden Delicious' apples at harvest and after 100 days of cold storage.

\begin{tabular}{lccccccc}
\hline & $\begin{array}{c}\text { Visual } \\
\text { aspect }\end{array}$ & $\begin{array}{c}\text { Firmness to } \\
\text { the touch }\end{array}$ & Texture & Crunchy & Juiciness & Mealiness & $\begin{array}{c}\text { Flavor } \\
\text { intensity }\end{array}$ \\
\hline $\mathbf{2 0 1 4}$ & & & & & & & \\
\hline Harvest & $8.1 \mathrm{a}$ & $9.0 \mathrm{a}$ & $5.1 \mathrm{a}$ & $4.3 \mathrm{a}$ & $6.1 \mathrm{a}$ & $3.1 \mathrm{~b}$ & $5.9 \mathrm{a}$ \\
Control & $5.1 \mathrm{~b}$ & $5.9 \mathrm{~b}$ & $2.8 \mathrm{~b}$ & $2.4 \mathrm{~b}$ & $3.7 \mathrm{~b}$ & $5.9 \mathrm{a}$ & $3.5 \mathrm{~b}$ \\
LOT & $5.8 \mathrm{~b}$ & $6.7 \mathrm{~b}$ & $3.6 \mathrm{ab}$ & $3.3 \mathrm{ab}$ & $4.9 \mathrm{ab}$ & $5.3 \mathrm{a}$ & $5.3 \mathrm{a}$ \\
\hline $\mathbf{2 0 1 5}$ & & & & & & & \\
\hline Harvest & $8.3 \mathrm{a}$ & $8.6 \mathrm{a}$ & $4.8 \mathrm{a}$ & $4.0 \mathrm{a}$ & $5.8 \mathrm{a}$ & 4.3 & $5.1 \mathrm{a}$ \\
Control & $5.4 \mathrm{~b}$ & $6.3 \mathrm{~b}$ & $2.5 \mathrm{~b}$ & $1.5 \mathrm{~b}$ & $4.0 \mathrm{~b}$ & 5.0 & $4.5 \mathrm{a}$ \\
LOT & $6.0 \mathrm{~b}$ & $6.5 \mathrm{~b}$ & $2.5 \mathrm{~b}$ & $2.5 \mathrm{~b}$ & $6.0 \mathrm{a}$ & 5.0 & $3.0 \mathrm{~b}$ \\
\hline $\mathbf{2 0 1 6}$ & & & & & & & \\
\hline Harvest & $8.6 \mathrm{a}$ & $9.2 \mathrm{a}$ & $5.3 \mathrm{a}$ & $3.8 \mathrm{a}$ & $6.6 \mathrm{a}$ & $2.2 \mathrm{c}$ & $6.7 \mathrm{a}$ \\
Control & $3.2 \mathrm{c}$ & $6.8 \mathrm{~b}$ & $1.9 \mathrm{c}$ & $1.3 \mathrm{~b}$ & $2.9 \mathrm{c}$ & $6.6 \mathrm{a}$ & $2.9 \mathrm{c}$ \\
LOT & $5.6 \mathrm{~b}$ & $6.4 \mathrm{~b}$ & $3.5 \mathrm{~b}$ & $2.6 \mathrm{ab}$ & $5.6 \mathrm{~b}$ & $4.1 \mathrm{~b}$ & $4.3 \mathrm{~b}$ \\
\hline
\end{tabular}

This technology was also combined with Dynamic Controlled Atmosphere (DCA) with $0.6-0.8 \%$ of $\mathrm{O}_{2}$ and $1.0-1.2 \%$ of $\mathrm{CO}_{2}$. For 2015 season, after 6 months of storage and for certain parameters (Figure 1), LOT followed by cold storage have the same 
effect than DCA (with or without LOT) for mold rots and firmness, and only for ethylene production, DCA provided a better response. For all of this, although DCA is the best option for preserving apples, LOT might be a promising and a more affordable alternative.
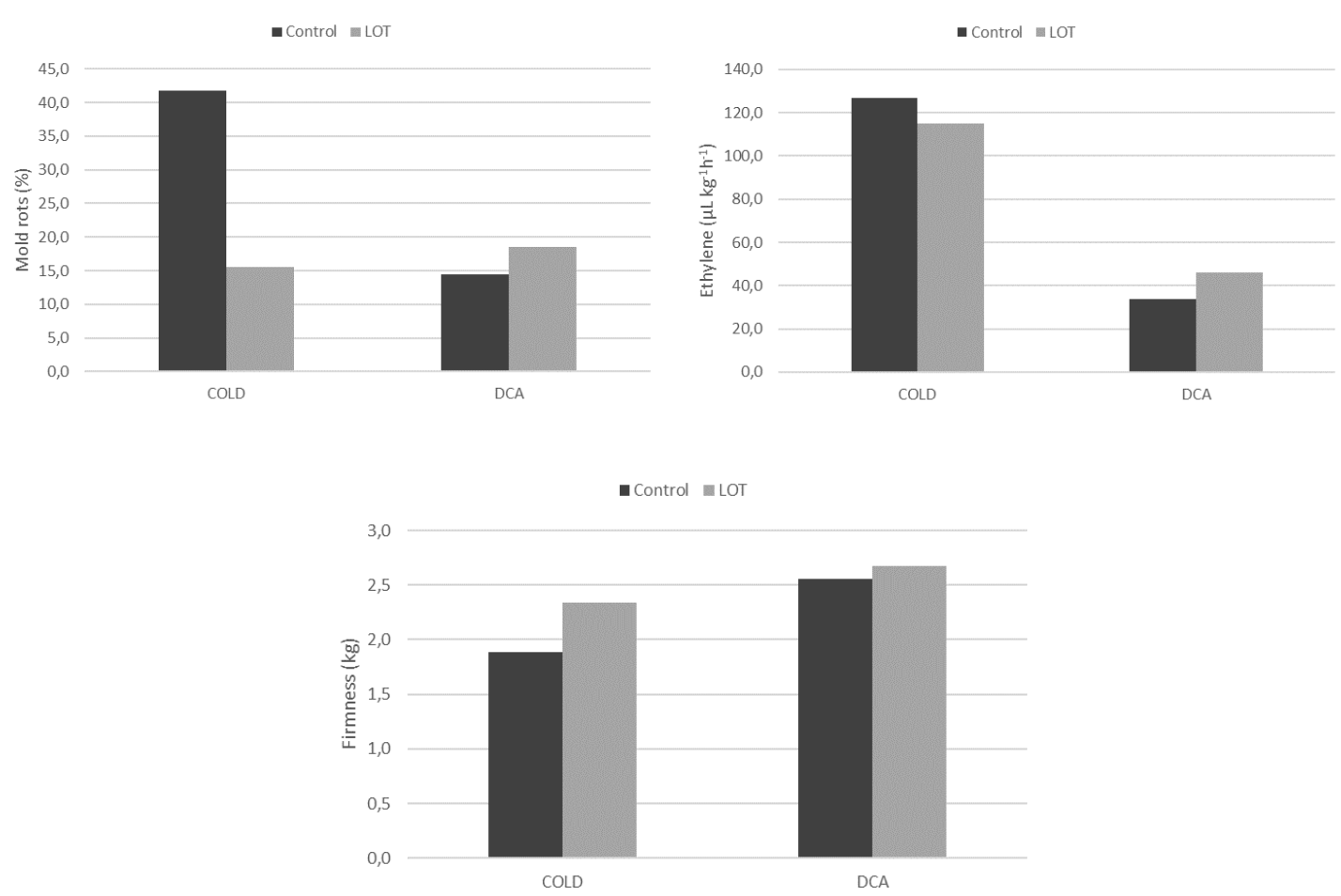

Figure 1. Effect of cold storage and DCA in 'Golden Delicious' apples without or with LOT after 6 months of storage.

LOT was also tested in other varieties such as 'White Reinette' in 2015 season (harvest on September 29, 2016) (Table 5). Again, the treatment was effective to maintain the firmness of apples after 100 days of storage, possibly due to the decrease observed in the production of ethylene. Moreover, LOT reduces the incidence of mold rots (from 4.0 to $0.8 \%$ ) although again increases scald (from 0.0 to $6.0 \%$ ). No effect in bitter pit and lenticel blotch pit was observed.

Table 5. quality and physiological parameters in 'White Reinnete' apples at harvest and after 100 days of cold storage*.

\begin{tabular}{lcccccc} 
& $\begin{array}{c}\text { Firmness } \\
(\mathrm{kg})\end{array}$ & Aweta & $\begin{array}{c}\text { SSC } \\
\left({ }^{\circ} \text { Brix }\right)\end{array}$ & $\begin{array}{c}\text { TA } \\
(\mathrm{g} \text { malic acid kg-1) }\end{array}$ & $\begin{array}{c}\mathrm{O}_{2} \\
\left(\mu \mathrm{kg}^{-1} \mathrm{~h}^{-1}\right)\end{array}$ & $\begin{array}{c}\text { Ethylene } \\
\left(\mu \mathrm{kg}^{-1} \mathrm{~h}^{-1}\right)\end{array}$ \\
\hline $\mathbf{2 0 1 6}$ & & & & & & \\
\hline Harvest & $9.35 \mathrm{a}$ & $28.54 \mathrm{a}$ & $12.34 \mathrm{~b}$ & 9.60 & $16.20 \mathrm{a}$ & $0.12 \mathrm{c}$ \\
Control & $3.77 \mathrm{c}$ & $8.09 \mathrm{~b}$ & $14.80 \mathrm{a}$ & 8.19 & $9.90 \mathrm{~b}$ & $42.19 \mathrm{a}$ \\
LOT & $5.53 \mathrm{~b}$ & $9.47 \mathrm{~b}$ & $13.88 \mathrm{a}$ & 9.24 & $10.01 \mathrm{~b}$ & $28.84 \mathrm{~b}$ \\
\hline
\end{tabular}

Our results indicate the application of LOT at industrial scale prior to cold storage may be a promising strategy to maintain fruit quality of apples. From this study we are able to propose the following:

\section{CONCLUSIONS}


- The application of low oxygen treatment during 10 days at room temperature is effective to maintain destructive and non-destructive firmness after 100 days of storage, with slight effect in the rest of quality parameters.

- LOT decreases the consumption of oxygen and the production of ethylene, indicating that this treatment might affect the respiration rates of these fruits and therefore, increase their shelf-life.

- LOT is effective to reduce the incidence of lenticel blotch pit and mold rots in 'Golden Delicious' apples. However, the treatment increases the appearance of superficial scald.

- Sensorial analysis shows better ratings for LOT samples for all the taste phase parameters than control fruits with no off flavors or fermented aromas.

- LOT might be an alternative for the DCA, which is the best option for the storage of most apple varieties studies so far.

- The effectiveness of this treatment has also validated in 'White Reinette' apples.

- In addition, these low-impact procedures are environmentally friendly and do not require the addition of chemicals to preserve fruit quality and can be an interesting technology to improve the shelf-life of pome fruits.

\section{ACKNOWLEDGEMENTS}

This work has been co-funded by y the CDTI (Centro para el Desarrollo Tecnológico Industrial of the Government of Spain) with the support of FEDER in the project "Reducción de fisiopatías en manzana mediante la aplicación de Tratamientos Postcosecha Combinados de Bajo Impacto - ManzImpacto" led by the company SAT DYMA.

\section{Literature Cited}

Benítez, C.E. (2001). Cosecha y Poscosecha de Peras y Manzanas en los Valles Irrigados de la Patagonia. (General Roca, Río Negro, Argentina: INTA). pp.126.

Pérez, M., Díaz, A., Blanco, A., Remón, S., Val J. (2012) Tratamientos físicos postcosecha para mejorar la calidad de la manzana Golden. En: Avances en poscosecha de frutas y hortalizas, Recasens I, Graell J, Echeverría (eds): pp. 451-456. Edicions de la Universitat de Lleida

Pérez, M., Remón, S., Díaz, A., Redondo, D., and Val, J. (2016) Tratamientos físicos de bajo impacto para mitigar alteraciones fisiológicas de las manzanas. Actas Portuguesas de Horticultura. 28: 139-145

Pesis, E., Ben-Arie, R., Feygenberg, O., Lichter, A., Gadiyeva, O., Antilofyev, I. and Uryupina, T. (2007). A simple pretreatment with low 02 to alleviate superficial scald in Granny Smith apples. J Sci Food Agric. 87, 1836-1844. http://doi.org/10.1002/jsfa.2873

Val, J., Fernández, V., López, P., Peiró, J. M., and Blanco, A. (2010). Low oxygen treatment prior to cold storage decreases the incidence of bitter pit in 'Golden Reinders' apples. Journal of the Science of Food and Agriculture, 90(3), 536-540. http://doi.org/10.1002/jsfa.3837. 